Неоплатонический пафос идейного компонента «Приятного и Благого» формирует такую интерпретацию эмфазы.

Роман «Время ангелов» уже привлекал внимание специалистов, однако продолжает оставлять место для истолкований. Вероятно, в романе просматривается идея перевернутого мира, релятивности ценностей, не абсолютности Добра и Зла (открытая концовка романа, смерть Карела, ведет к преображению, к продуцированию Добра). Именно это приводит писательницу к полемике с экзистенциализмом, которому она противопоставляет платоновскую концепцию единства Красоты и Добра.

\title{
Литература:
}

1. Ливергант А. Вариации на тему: «О последних романах А.Мердок». Литературное обозрение, 1986. №1.

2. Martz I. Iris Murdoch: The London Novels. Twentieth Century Literature in Retrospect. L.,1971.

3. Johnson D. Iris Murdoch. L., 1987.

4. Conradi P. I. Murdoch: The Saint and The Artist. L., 1986.

5. Левидова И. Послесловие. Мердок А. Дитя слова. М., 1981.

6. Мердок А. Время ангелов. С.П., 1995.

DOI https://doi.org/10.30525/978-9934-26-073-5-1-22

\section{ЦІННІСНІ АСПЕКТИ МОДЕЛЮВАННЯ ФІКЦІЙНОЇ СВІДОМОСТІ ПЕРСОНАЖА В ДРАМІ Ю. ЯНОВСЬКОГО «ДОЧКА ПРОКУРОРА»}

\author{
Атаманчук В. П. \\ доктор філологічних наук, дочент, \\ провідний науковий співробітник \\ відділу організачії наукових досліджень \\ Національного педагогічного університету імені М. П. Драгоманова \\ м. Київ, Украӥна \\ У драмі Ю. Яновського «Дочка прокурора» (1953) значна увага \\ приділяється визначенню моральних параметрів дійових осіб з огляду на \\ відтворену у п'єсі драматичну ситуацію та окресленню ціннісних \\ трендів у суспільстві. Тому дослідження процесу моделювання фікційної
}


свідомості персонажів у творі здійснюється крізь призму ціннісних орієнтирів.

Одним із найважливіших ціннісних аспектів у драмі виявляється проблема відповідальності, яка осмислюється автором 3 урахуванням різних рівнів фікційної свідомості дійових осіб та з урахуванням різних рівнів буття персонажів - індивідуального, міжособистісного, суспільного. Показуючи протиборство персонажів, зумовлене різнорівневістю їхньої фікційної свідомості, письменник генерує конфлікт, який концентрично розширюється, охоплюючи усі сфери життєдіяльності дійових осіб, що являють різні проекції стану моралі та усвідомленості героїв п’єси.

Відображення процесів фікційної свідомості героїв у художніх творах передбачає конструювання непізнаваних, нематеріальних сфер, що не піддаються однозначному визначенню, через уявлення, які формуються на основі відтворення видимих явищ. Таким способом окреслюються різні рівні відображення за характеристикою матеріальної репрезентації у художньому творі. Водночас співвідношення між пізнаваним і непізнаваним, матеріальним та ідеальним детермінують особливості побудови художньої структури як єдиного цілого. Т. Адорно простежує подібні процеси на рівні функціонування художніх творів як феноменів мистецтва: «Ілюзійний характер художніх творів іманентно опосередковується їхньою власною об'єктивністю» [1, с. 149].

Екстраполяція подібних суджень на драму «Дочка прокурора» створює можливості для аналізу та інтерпретації прикметних ознак функціонування фікційної свідомості дійових осіб у різних вимірах, насамперед, духовному та фізичному. Духовний вимір у драмі пов'язується із різними здатностями різних героїв твору до апперцепції, проективного конструювання, подальшої корекції та формування нових рівнів сприйняття й усвідомлення. Співвідношення між цими здатностями та їхньою наповненістю істотно відрізняється у всіх дійових осіб; важливим параметром для порівнянь героїв у драмі виявляється їхня спроможність до об'єктивних оцінок внутрішніх та зовнішніх реалій. Фізичний вимір ототожнюється із вчинками та реакціями героїв, що мають зовнішне вираження, у результаті яких відбувається розвиток дії та формування драматичного конфлікту.

Г. Гачев визначає специфіку драматичного конфлікту, підкреслюючи його динаміку. Водночас дослідник акцентує увагу на процесі діяльності, що у драматичному творі стає універсальним засобом і показником вияву будь-яких інтенцій. Він стверджує: «Бо в діяльності відбувається конфлікт і узгодженість світу і людини, життя і духа» [2, с. 274]. 
О. Клековкін, даючи визначення драматичному конфлікту, розкриває його сутність. Науковець перераховує імовірні аспекти боротьби, виокремлюючи поняття свідомості як один із можливих компонентів протиборства: «Сторони конфлікту ведуть боротьбу за предмет конфлікту - об'єкт драматичної боротьби (людину, іiї свідомість, вчинки, об'єкти матеріального світу)» [3, с. 301].

У драмі «Дочка прокурора» боротьба відбувається у сфері фікційної свідомості дійових осіб твору, оскільки твір репрезентує складні процеси внутрішніх та зовнішніх борінь, які утворюють достатньо заплутані сюжетні переплетення, що посилюють внутрішні реакції, спричинені намаганнями героїв подолати особистісні та суспільні суперечності. Характерною стильовою прикметою драми виявляється втілена естетика реалізму, що простежується не лише у зображенні зовнішніх реалій, але й у відтворенні внутрішніх та зовнішніх взаємозумовленостей, які підкреслюють інтенсивність та складність процесів, які відбуваються у фікційній свідомості дійових осіб.

Розгортання конфлікту драми базується на показові вихідних умов $\mathrm{i}$ параметрів, які стають першопричинами накопичення імпульсів критичних ситуацій в особистісних взаємодіях, що у результаті призводять до появи взаємозалежних антагоністичних позицій. Письменник відтворює зародки протистояння у взаєминах членів родини прокурора, які 3 розвитком драматичної дії перетворюються на серйозний повномасштабний конфлікт, що одержує суспільний резонанс. Конструюючи конфлікт п'єси, драматург використовує принцип проекцій, за допомогою яких він показує одне явище у різних відображеннях, які взаємно підсилюються через зіставлення та визначення їхніх першооснов.

Письменник підкреслює парадокси особистісних взаємин та їхні наслідки, які визначають сутність драматичного конфлікту п’єси. У творі показані реалії життя дорослих та підлітків, що становлять два окремих світи, спосіб взаємодії яких характеризується складними суперечностями, спричиненими істотними непорозуміннями внаслідок різного світосприйняття. Письменник акцентує увагу на рушійних силах конфлікту, зіставляючи внутрішню вразливість підлітків та психологічне збайдужіння дорослих.

Конфлікт драми «Дочка прокурора» формується у морально-етичній та духовній площині, відображаючи різні рівні фікційної свідомості дійових осіб. Водночас конфлікт утворюється внаслідок тривалого утримування деструктивних позицій одних дійових осіб, та позицій вимушених жертв інших персонажів. У результаті найбільшого напруження, викликаного зовнішніми перипетіями і внутрішніми реакціями 
героїв, відбувається усвідомлення причин і наслідків заплутаного конфлікту у фіналі твору, що призводить до його вирішення. Нил Микитович досягає вищого рівня свідомості у результаті осмислення усієї конфліктної ситуації, сформованої діями та бездіяльністю дорослих, що призводить до знімання напруги в міжособистісних та суспільних взаємодіях.

\title{
Література:
}

1. Адорно Т. Теорія естетики / пер. 3 нім. П. Таращук. К.: Видавництво Соломії Павличко «Основи», 2002. 518 с.

2. Гачев Г. Д. Содержательность художественных форм. Эпос. Лирика. Театр. Москва: Просвещение, 1968. 302 с.

3. Клековкін О. Ю. Theatrica. Морфологія: лексикон. К.: Арт Економі, 2011. 444 с.

DOI https://doi.org/10.30525/978-9934-26-073-5-1-23

\section{ХУДОЖНС ОСМИСЛЕННЯ ТА ТЛУМАЧЕННЯ КАТЕГОРІЇ ЧАСУ ТА ПРОСТОРУ У ЛІРИЦІ Є. ПЛУЖНИКА}

\author{
Білічак О. I. \\ кандидат філологічних наук, \\ викладач кафедри мовознавства, \\ Івано-Франківського начіонального медичного університету \\ м. Івано-Франківськ, Украӥна
}

Художнього осмислення і тлумачення набувають у ліриці Є. Плужника філософські категорії часу та простору. В. Халізєв виділяє образи часу біологічного (дитинство, юність, зрілість, старість), історичного (характеристики зміни епох і поколінь, великих подій у житті суспільства), космічного (уявлення про вічність та вселенську історію), календарного (зміна пір року, буднів та свят), добового (день і ніч, ранок i вечір), а також уявлення про рух і нерухомість, про співвідношення минулого, теперішнього, майбутнього [1, с. 26]. Останню із названих категорій можна окреслити як час екзистенційний.

Для ліричного героя сьогодення не сприймається крізь призму історичного минулого, яке у своєму трагізмі сягнуло героїчних висот. Герой живе у часі, яке не $\epsilon$ ідеальним продовженням громадянських поступів минулого, він розчарований реальною дійсністю, однак його 94 